\title{
HEMT SMOKING
}

\section{DR. MUMTAZ ALI SHAIKH}

FCPS Medicine; D.Card

Associate Professor of Medicine

Liaquat University of Medical and Health Sciences

Jamshoro/Hyderabad Sind Pakistan

\section{DR. DUR-E-YAKTA}

Assistant Prof Ophthalmology

GMMMC SUKKER SMBBU, Larkana

\section{DR. DARGAHI SHAIKH}

Senior Anaesthetist

SMBBU, Larkana

ABSTRACT... Objective: This study is conducted to observe the serum lipoprotein alterations in chronic heavy smokers in LUMHS Sindh. Study Design: Analytical study Material and Methods: It was conducted on 60 non obese adult smokers, both sexes, who smoked more than twenty cigarettes or beeries a day regularly for more than five years. All the participants were current smokers. Sampling technique was simple random technique. Setting: The study was conducted in outdoor department of LUMHS Jamshoro/Hyderabad. Period: Jan 2010 to Jan 2011. Eighteen hours fasting blood sample was sent for lipid studies. Lipids studied were serum cholesterol, serum triglycerides, high density lipoproteins and low density lipoproteins. For control values ATP 3 guidelines were used. Statistics: Mean of statistical values was calculated with standard deviation and variance in standard deviation. Results obtained were analyzed by SPSS 11. Results: Age of the patients was 2570 years. Mean age was $47.81 \pm 12.96$ years. Median age was 50 years. Male/ female ratio was $45 / 15$. Patients were from both rural and urban areas. Mean duration of smoking was $25.5 \pm 9.15$ years. The study carried out on 60 chronic heavy smokers, showed deranged lipid levels as: Total cholesterol mean $237.57 \mathrm{mg} / \mathrm{dl} \pm 37.89$; TG mean $203.76 \mathrm{mg} / \mathrm{dl} \pm 47.08$; LDL-C mean 158.62 mg/dl $\pm 17.25 ;$ HDL-C mean 29.67 mg/dl \pm 3.12 . Results are shown in Table No I. Conclusions: Our study concluded at LUMHS showed that by continuous heavy smoking the serum lipid levels get deranged.

Key words: Smoke, Lipids, Sindh.

\section{INTRODUCTION}

Smoking is a recognized risk factor that leads to alteration of the serum lipoprotein pattern. The most probable way by which cigarette smoking increases risk of myocardial infarction is by altering the levels of lipoproteins. Tobacco smokers have arterial changes associated with preclinical atherosclerosis. Long-term exposure to smoke is estimated by measuring blood levels of cotinine, a byproduct of nicotine. Further research has shown that maximum intima/media thickness in both the carotid and aorta increased, as exposure to cigarette smoking increased, and endothelial function as measured by brachial artery flowmediated dilation was decreased and in addition, (apoprotein) apoB and apoB/apoA-I ratio increased with increases in cotinine level ${ }^{1}$. Cigarette smoking is quite common in our country. Smoking is an increasing public health problem especially in Pakistan. It is a risk factor for accelerated atherosclerotic vascular diseases ${ }^{2}$.

One of studies done at Islamabad students it was found that $12.6 \%$ were regularly smoking cigarettes ${ }^{3}$. Another study at Karachi showed that overall, $23 \%$ of students (31\% male and $6 \%$ female) were classified as regular smokers ${ }^{4}$. Study at Sind showed, that high number (10\%) of adult women were smokers ${ }^{5}$. Tobacco smoke contains many constituents; nicotine is one of the main constituents. Nicotine causes increase in triglyceride TG, cholesterol and very low density lipoproteins VLDL levels and decrease in High density lipoproteins HDL levels ${ }^{6}$. Considering the smoking as major risk factor for heart diseases which happens due to alteration in serum lipoproteins; this study is carried out to observe the alterations in plasma fasting total lipids, triglycerides, total cholesterol, HDL-C and low density lipoprotein LDL$\mathrm{C}$ in chronic heavy smokers at LUMHS Sindh.

\section{METHODOLOGY}

This prospective, descriptive and analytical study was conducted on 60 non obese adult smokers, both sexes, who smoked more than twenty cigarettes or beeries a day regularly for more than five years. All the participants were current smokers. Sampling technique was random technique. The study was conducted in outdoor 
department of LUMHS Jamshoro/Hyderabad from Jan 2010 to Jan 2011. Diabetics, hypertensive, primary dyslipidaemics, alcoholics, hepatic or renal disease, obesity, patients taking any medicines like B-blockers, diuretics or lipid lowering agents and patients with any other serious illness were excluded from the study. Eighteen hours fasting blood sample was sent for lipid studies. Lipids studied were Serum cholesterol, serum triglycerides, high density lipoproteins and low density lipoproteins. Obesity was excluded by calculating Body Mass Index. Normal values of fasting lipid profile were taken as;

\section{Total cholesterol desirable}

Triglycerides

High density lipoprotein cholesterol

Low density lipoprotein cholesterol (ATP 3 guidelines).

$<200 \mathrm{mg} / \mathrm{dl}$. $<150 \mathrm{mg} / \mathrm{dl}$. $>40 \mathrm{mg} / \mathrm{dl}$ $<130 \mathrm{mg} / \mathrm{dl}$,

\section{STATISTICS}

Mean of statistical values was calculated with standard deviation and variance in standard deviation. Results obtained were analyzed by SPSS 11 .

\section{RESULTS}

Age of the patients was 25-70 years. Mean age was $47.81 \pm 12.96$ years. Median age was 50 years. Male/ female ratio was $45 / 15$. Patients were from both rural and urban areas. Mean duration of smoking was $25.5 \pm 9.15$ years. The study carried out on 60 chronic smokers, showed deranged lipid levels as: Total cholesterol mean $237.57 \mathrm{mg} / \mathrm{dl} \pm 37.89$; TG mean $203.76 \mathrm{mg} / \mathrm{dl} \pm 47.08$; LDL-C mean $158.62 \mathrm{mg} / \mathrm{dl} \pm 17.25$; HDL-C mean 29.67 $\mathrm{mg} / \mathrm{dl} \pm 3.12$. Results are shown in Table-II.

\section{DISCUSSION}

This study revealed that all chronic heavy smokers in our set up had lipid levels deranged. Their mean levels were total cholesterol mean $237.57 \pm 37.89 \mathrm{mg} / \mathrm{dl}$; TG mean $203.76 \pm 47.08 \mathrm{mg} / \mathrm{dl} ;$ LDL-C mean $158.62 \pm 17.25 \mathrm{mg} / \mathrm{dl}$; HDL-C mean $29.67 \pm 3.12 \mathrm{mg} / \mathrm{dl}$ (Table I). These results were significant and comparable to results of other studies. One of the studies carried out has proved that in smokers the levels of total cholesterol, LDL-C were significantly elevated when compared with the controls ${ }^{7}$.

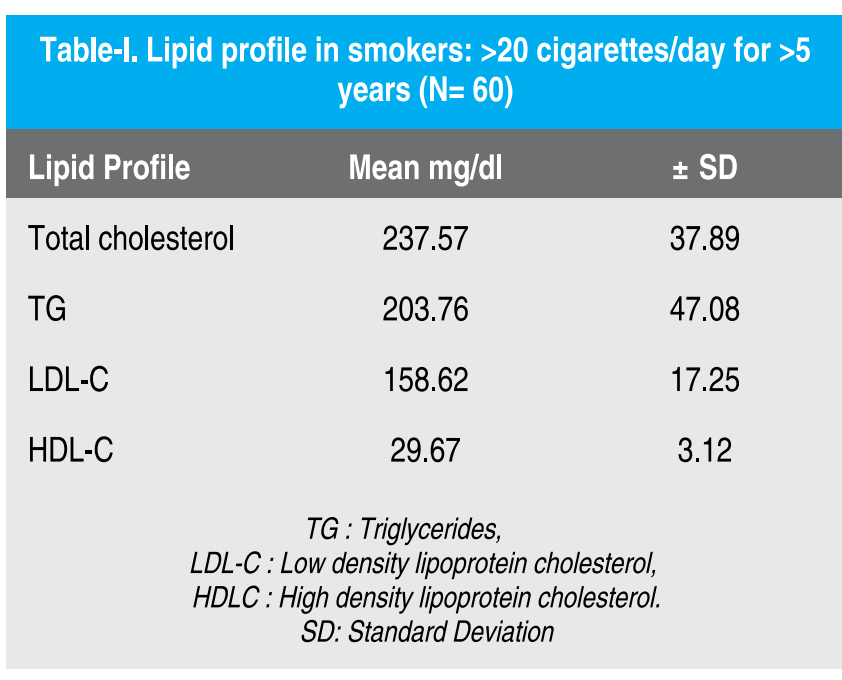

Another study has shown that smokers have significantly higher ESR values, serum total cholesterol, LDL-C and mean serum TG levels. Mean serum HDL-C was significantly lower in smokers as compared to non smokers ${ }^{8}$. Another study has shown that smokers tend to have significantly high incidence of multi-vessel disease ${ }^{9}$. It has been observed that obesity and smoking are dangerous diseases which are becoming epidemic problems around the whole world including Pakistan and are quite evident risk factors for heart and vascular diseases. It is further associated with lipoprotein derangement and diabetes mellitus ${ }^{10}$. Other study has shown that smoking produces adverse effects on lipid profile, therefore increasing the cardiovascular disease risk $^{11}$. Tobacco smoke contains more than 4000 chemicals including 43 that are known to cause cancer ${ }^{12}$. Another study has shown that smokers, total cholesterol, TG, and LDL-C are increased and HDL-C is markedly decreased showing greater risk of these persons to atherosclerosis and coronary heart disease ${ }^{13}$. According to the Framingham study ex-smokers who quit smoking for more than one year have serum cholesterol levels similar to non-smokers. This means that smokers who can stay quit for one year or more may normalize their lipid profiles. Smoking cessation improved HDL-C, total HDL-C, and large HDL-C particles, especially in women $^{14}$. The findings indicate that the start of even modest cigarette smoking may have potentially longterm atherogenic effects. Prevention of smoking in early life should therefore be an important aspect of cardiovascular disease intervention ${ }^{15}$. 


\section{CONCLUSIONS}

It has been concluded from this study that by continuous heavy smoking the serum lipid levels get deranged.

\section{Copyright@ 27 April, 2012.}

\section{REFERENCES}

1. Kallio K, Jokinen E, Saarinen M, Hamalainen M,Valanin I, Katosari T, et al. Arterial intima-media thickness, endothelial function, and apolipoproteins in adolescents frequently exposed to tobacco smoke Circulation. 2011;123:3292-298.

2. Heitzer T, Just $\mathrm{H}$, Munzel T. Antioxidant vitamin C improves endothelial dysfunction in chronic smokers. Circulation 1996; 94:6-9.

3. Masood S, Anila K. Prevalence and pattern of smoking in university students: Perspective from Islamabad. JCPSP 2004;14:194-5.

4. Rashid A, Rizwanur R, Paul W, Wajid A. Prevalence of cigarette smoking among young adults in Pakistan. $J$ Pak Med Assoc Nov 2008;58:597-601.

5. Sajid A, Naseem A, Arif A, Beena A, Masood K Knowledge and practices regarding cigarette smoking among adult women in a rural district of Sindh, Pakistan. J Pak Med Assoc 2008;58:664-6.

6. Cluette B, Hugan. S. Oral nicotine induces an atherogenic lipoprotein profile. Proc. Soc. Exp. Bio. Med 1986:182:409-13.

7. Mehrun N, Samina Z. Study of erythrocyte sedimentation rate (ESR) values and serum lipids in young cigarette smokers. Proceeding Shaikh Zayed Postgrad Med Inst 2003;17:71-3.

8. Neki N. Lipid Profile in Chronic Smokers - A Clinical Study. JIACM 2002; 3: 51-4.

9. Mansoor A, Dad J, Faisal M,, Moin K, Shafique M, Anwar A. Pattern of Coronary Atherosclerosis in smokers and non-smokers. Pak Heart J 2003;36:20-5.

10. Venkatesn A, H ehalatha A, Zacharih N, SelvarajA. Effect of smoking on lipid profile and lipid peroxidation in normal subjects. Indian J Physiol Pharmacol 2006; 50 (3) : 273-278

11. http://www.drugs.com/news/acomplia-rimonabant-studysmoking-obesity-one-pill-them-both-3479.html Accessed on $9 / 2 / 11$

12. Zila $\mathrm{R}$, Ataur $\mathrm{R}$. Role of nicotine, cotinine and thiocyanate in cigarette smoking: (active and passive). Med Channel 2006;12:7-11.

13. Zamir A, Muhammad S, Muhammad S. Lipid profile in smoking. JAMC 2000;12:19-24.

14. Adam D, Megan E, Heather M, Michael C, Timothy B, James H. Effects of Smoking and Smoking Cessation on Lipids and Lipoproteins: Outcomes from a Randomized Clinical Trial. American Heart Journal. 2011;161:145-151.

15. Willium R, Sathanur R, Charles L, Saundra M, Janet B, Larry $S$, et al. Cigarette smoking initiation and longitudinal changes in serum lipids and lipoproteins in early adulthood The Baglusa heart study. American Journal of Epidemiology 2011, 124; 207-19.

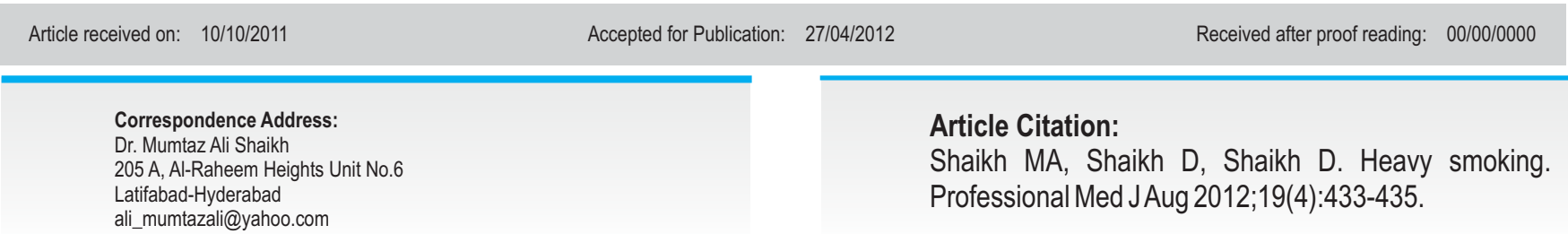

\section{PREVIOUS RELATED STUDIES}

Noreen Rahat Hashmi, Seema Daud, Iram Manzoor, Khalid Maqsood, Shezad saleem, Usman Javaid SMOKING PATTERNS. (Original) Prof Med Jour 16(3) 384-389 Jul, Aug, Sep, 2009.

Shah Nawaz Hassan Gardezi, PASSIVE SMOKING (Review) Prof Med Jour 12(4)354-356 Oct, Nov, Dec 2005. 